\title{
PENGARUH LAMA PENGERINGAN TERHADAP SIFAT FISIKO KIMIA TEH DAUN KERSEN (Muntingia calabura L.)
}

Eka Hely ${ }^{2}$, Mohammad Abbas Zaini 2 dan Ahmad Alamsyah 2

${ }^{1}$ Fakultas Teknologi Pangan dan Agroindustri Universitas Mataram, Email: ekahellye@gmail.com

${ }^{2}$ Fakultas Teknologi Pangan dan Agroindustri Universitas Mataram

INFO ARTIKEI

\section{RiwayatArtikel:}

Diterima: 15-02-2018

Disetujui: 21-02-2018

\section{Kata Kunci: \\ Antioxidant \\ Drying Time \\ Tea}

\begin{abstract}
ABSTRAK
Abstrak: Penelitian ini bertujuan untuk mengetahui pengaruh lama pengeringan terhadap sifat fisiko kimia terhadap aktivitas antioksidan, kadar air, kadar abu, kadar ekstrak dalam air dan organoleptik (warna, rasa dan aroma) teh daun kersen (Muntingia calabura L.).Penelitian ini dirancang menggunakan Rancangan Acak Kelompok (RAK) untuk parameterfisik, kimia maupun organoleptik dengan 6 perlakuan dan 3 ulangan. Hasil pengamatan dianalisis menggunakan analisis keragaman ANOVA (Analysis of Variance) menggunakan Software Costat serta menggunakan uji lanjut Polynomial Ortogonal dan Duncan Multiple Range Test ( $\mathrm{p}$ $<0,05$ ). Perlakuan terdiri dari satu faktor yaitu lama pengeringan 120,130, 140, 150, 160 dan 170 menit dengan suhu yang sama yaitu $50{ }^{\circ} \mathrm{C}$. Hasil Penelitian menunjukkan bahwa lama pengeringan dalam pembuatan teh daun kersen memberikan pengaruh yang berbeda nyata terhadapkadar air, parameter organoleptik rasa, aroma (hedonik), rasa, aroma, warna (scoring) dan memberikan pengaruh yang tidak berbeda nyata terhadap aktivitas antioksidan, kadar abu, ekstrak dalam air dan organoleptik warna (hedonik). Hasil penelitian ini juga menunjukkan bahwa pengeringan selama 170 menit menghasilkan teh daun kersen dengan mutu terbaik untuk kadar air 3,05\%, aktivitas antioksidan 88,60\%, kadar abu 7,58\% dan kadar ekstrak dalam air 7,58\%, sedangkan untuk parameter organoleptik pada pengeringan 120 menit dengan warna (Kuning kehijauan), aroma (kersen agak khas) yang disukai serta rasa (kersen pahit) yang tidak disukai oleh panelis.dengan warna,aroma yang disukai serta rasa yang tidak disukai oleh panelis.
\end{abstract}

Abstract: This study aimed to determine the effect of drying time on the physico chemical properties of antioxidant activity, moisture content, ash content, extract content on water content and organoleptic (color, taste and aroma) of cherry leaf (Muntingia calabura L.) tea. This study was designed using Randomized Block Design (RBD) for physical, chemical and organoleptic parameters with 6 treatments and 3 replications.Results were analyzed by analysis of variance (ANOVA) using Co-stat software and analyzed further by Polynomial Orthogonal and Duncan Multiple Range Test ( $p<0.05)$. Treatment consisted of single factor: drying time $(120,130,140,150,160$ and 170 minutes with same temperature (50 C). Results showed that the drying time in the production of cherry leaf tea gave a significantly different effect on moisturecontent, taste and aroma (hedonic), as well as taste, aroma and color (scoring), but gave unsignificant effect on antioxidant activity, ash content, extract content in water andcolor (hedonic). The results of this study also showed that drying time up to 170 minutes produced cherry leaf tea with the best chemical qualities(water content 3,05\%, antioxidant $88,60 \%$, ash content $7,58 \%$ and extract content in water $7.58 \%$ ), whilebest organolepticqualities produced atdrying up to 120 minutes with preferred color (greenish yellow) and aroma (rather typical cherry), but with unpreferredflavor (bitter cherry) by the panelists. 


\section{A. LATAR BELAKANG}

Tanaman teh merupakan tumbuhan berdaun hijau yang termasuk dalam keluarga Camellia yang berasal dari Cina, Tibet dan India bagian utara.Teh adalah minuman yang mengandung kafein, sebuah infusi yang dibuat dengan cara menyeduh daun, pucuk daun, atau tangkai daun yang dikeringkan dari tanaman Camelia sinensis dengan air panas.

Teh juga merupakan sumber alami kafein, teofilin dan antioksidan dengan kadar lemak, karbohidrat, atau protein mendekati nol persen. Teh bila diminum akan terasa sedikit pahit yang merupakan kenikmatan tersendiri dari teh (Ismadi, 2011).

Teh merupakan functional food mengingat khasiat dan potensi yang terkandung dalam teh dapat meningkatkan kesehatan tubuh dan merupakan sumber zat gizi. Di antara beberapa senyawa kimia yang paling besar peranannya dalam pembentukan cita rasa dan berbagai khasiat istimewa teh adalah katekin (Ayuningtyastuty, 2009). Teh tidak hanya bisa dibuat dari tanaman Camelia sinensis atau tanaman teh lainnya akan tetapi teh juga bisa dibuat dari tanaman kersen (Muntingia calabura L.).

Tanaman kersen (Muntingia calabura L.) adalah salah satu jenis tanaman yang biasanya digunakansebagai obat. Buah dari kersen ini diduga sebagai obat asam urat dan daunnya diduga sebagai obat anti diabetes

Tamanan kersen merupakan tanaman perdu yang tingginya mencapai 2-10 m dengan daun yang berderet dan dahan menjuntai. Daun kersen memiliki ciri bentuk daun lanset, permukaan bulunya halus, ujung daun runcing, pangkal daun tumpul, tepi daun bergerigi dengan panjang 4-14 cm dan lebar 1-4 cm, daging daun kersen menyerupai kertas dengan tulang daun mennyirip. Mahkota bunganya berbentuk bulat telur terbalik dan berwarna putih.

Berdasarkan penelitian pendukung bahwa penelitian mengenai proses pembuatan teh dari daun kersen belum banyak diteliti, adapun pembuatan teh daun kersen menggunakan oven cabinet dryer. Berdasarkan hasil penelitian (Adri, 2013) menyatakan bahwa proses pengeringanteh daun sirsak dilakukan selama 150 menit dengan suhu $50{ }^{\circ} \mathrm{C}$, kondisi operasional pengeringan daun sirsak pada suhu $50{ }^{\circ} \mathrm{C}$ dengan lama pengeringan 150 menit menghasilkan teh daun sirsak dengan aktivitas antioksidan tertinggi dan nilai EC50 terendah.

Pengeringan adalah proses penghilangan sejumlah air yang terkandung dalam bahan pangan sampai kadar air yang dikehendaki. Adapun tujuan utama proses pengeringan bahan pangan yaitu untuk meningkatkan umur simpan dan mengurangi berat atau volume bahan. Pengeringan dapat meningkatkan umur simpan karena terjadi pengurangan kadar air bahan, sehingga perkembangan mikroorganisme dan enzim yang menyebabkan kerusakan menjadi terhambat. Kadar air produk teh berkurang hingga tersisa sekitar $8 \% \quad \mathrm{~b} / \mathrm{b} \quad$ (Badan Standarisasi Nasional, 1995). Sehingga tujuan pengeringan pada prinsipnya adalah untuk menurunkan kadar air dari suatu produk pertanian sehingga memenuhi penggunaan selanjutnya (Matondang, 1989). Oleh karena itu, perlu dilakukan penelitian ini untuk mengetahui pengaruh lama pengeringan terhadap sifat fisiko kimia teh daun kersen (Muntingia calabura L.) agar dapat menghasilkan teh yang memiliki lama pengeringan terbaik.Penelitian ini bertujuan untuk mengetahui pengaruh lama pengeringan terhadap aktivitas antioksidan, kadar air, kadar abu, kadar ekstrak dalam air dan organoleptik (warna, rasa dan aroma) teh daun kersen. 


\section{B. METODE PENELITI AN}

Metode yang digunakan dalam penelitian ini adalah metode eksperimental yang dilaksanakan di Laboratorium.Rancangan percobaan yang akan dilakukan untuk mengetahui pegaruh lama pengeringan terhadap sifat fisiko kimia teh daun kersen adalah Rancangan Acak Kelompok (RAK) yang terdiri dari 6 aras dengan suhu yang sama yaitu $50{ }^{\circ} \mathrm{C}$ dengan ulangan perlakuan sebagai kelompok (blok) pada parameter nilai gizi dan parameter organoleptik. Rancangan percobaan menggunakan faktor tunggal, yakni lama pengeringan, sehingga perlakuannya sebagai berikut:

M1= Pengeringan selama 120 menit

M2= Pengeringan selama 130 menit

M3= Pengeringan selama 140 menit

M4= Pengeringan selama 150 menit

M5=Pengeringan selama 160 menit

M6= Pengeringan selama 170 menit

Masing-masing perlakuan diulang sebanyak 3 kali sehingga diperoleh 18 unit percobaan. Data pengamatan dianalisis dengan menggunakan Analysis of Varian (ANOVA) pada taraf 5\% menggunakan software Co-Stat. Adanya perbedaan yang nyata antar perlakuan, maka diuji lanjut dengan uji Beda Kecenderungan atau Metode Ortogonal Polinomial (MOP) pada taraf 5\% sedangkan adanya perbedaan yang nyata antar perlakuan pada uji organoleptik, maka data diuji lanjut menggunakan Uji Duncan's Multiple Range Test (DMRT) pada taraf 5\% (Hanafiah, 2014).

\section{BAHAN DAN ALAT}

\section{Bahan-Bahan Penelitian}

Bahan-bahan yang digunakan pada penelitian ini antara lain $15 \mathrm{ml}$ methanol,aquades, $1 \mathrm{ml}$ 0,01 mM DPPH. Sampel yang digunakan adalah daun kersen hijau tua (baris ke 4,5,6 dari pucuk) sebanyak 4 pohon dengan usia kurang lebih 5 tahun dan ketinggian pohon kurang lebih $7 \mathrm{~m}$ yang berasal dari Desa Terong

Tawah Kec. Labuapi Kab. Lombok Barat (Lobar).

\section{Alat-alat Penelitian}

Alat-alat yang digunakan pada penelitian ini antara lain tabung reaksi, loyang, gunting, timbangan digital, sealer, gelas ukur $5 \mathrm{ml}$, cawan petri, oven, pipet ukur $10 \mathrm{ml}$, pipet ukur $5 \mathrm{ml}$, pipet ukur $1 \mathrm{ml}$, pipet ukur $50 \mathrm{ml}$, bulb, oven Cabinet Dryer, mortar, cawan porselin, desikator, kertas saring, tanur dan spektrofotometer UV-vis.

\section{Tahapan Penelitian}

Proses pembuatan teh daun kersen meliputi beberapa tahapan yaitu persiapan bahan baku meliputi pembuatan teh daun kersen di antaranya proses penyiapan dau kersen, pemisahan dari tangkai, sortasi, pelayuan, penimbangan perajangan, pengeringan dan pengemasan

\section{Parameter Analisis}

Parameter yang diamati dalam penelitian ini adalah kualitas teh daun kersen meliputi sifat fisik, kimia dan organoleptik. Sifat kimia meliputi kadar air aktivitas antioksidan dan kadar abu. Sifat fisik meliputi kadar ekstrak dalam air. Sedangkan sifat organoleptik meliputirasa, aroma dan warna dengan menggunakan metode hedonik (kesukaan) dan scoring. 


\section{HASI L DAN PEMBAHASAN}

1. Mutu Kimia

Tabel 1. Hasil pengamatan keragaman kadar air, aktivitas antioksidan dan kadar abu

\begin{tabular}{cc}
\hline Parameter & Signifikansi \\
\hline Kadar Air & S \\
Aktivitas Antioksidan & NS \\
Kadar Abu & NS \\
\hline
\end{tabular}

Keterangan:

$\mathrm{S}=$ Signifikan (Berbeda nyata)

NS=Non Signifikan (Tidak berbeda nyata)

\section{Kadar Air}

BerdasarkanHasil uji lanjut polynomial ortogonal dapat diketahui pola kecendrungan perlakuan lama pengeringanteh daun kersen terhadap kadar air teh daun kersen dapat dilihat pada Gambar1

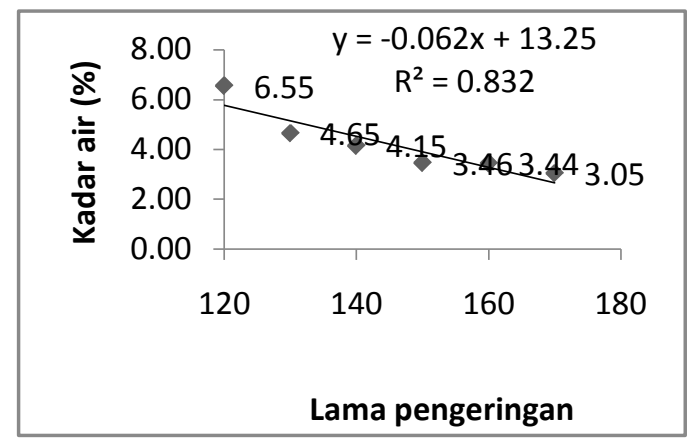

Gambar1.Grafik Pengaruh Lama Pengeringan terhadap Kadar Air Teh Daun Kersen

Gambar 1 menunjukkan bahwa Kadar air teh daun kersen tertinggi terdapat pada perlakuan lama pengeringan 120 menit yaitu 6,55\% dan kadar air terendah terdapat pada perlakuan 180 menit yaitu 3,05\%. Hal ini disebabkan laju penguapan air bahan dalam pengeringan sangat ditentukan oleh kenaikan suhu. Semakin besar perbedaan antara suhu media pemanas dengan bahan yang dikeringkan, semakin besar kecepatan pindah panas ke dalam bahan pangan sehingga penguapan air dari bahan akan lebih banyak dan semakin lama waktu pengeringan yang digunakan maka kadar air bahan semakin rendah dan menurunkan bobot bahan yang dikeringkan (Winarno, 1993). Hal inisejalan dengan hasil penelitian Hafiz (2008)dalam Sari (2011), bahwa dengan meningkatkan lamapengeringan 2 jam akan menurunkan kadar air sebesar 2,21\%. Hal ini disebabkanlaju penguapan air bahan dalam pengeringan sangat ditentukan oleh kenaikansuhu.

\section{Aktivitas Antioksidan}

Berdasarkan data hasil pengamatan dan analisis keragaman bahwa perlakuan lama pengeringan tidak berbeda nyata terhadap aktivitas antioksidanteh daun kersen dapat dilihat pada gambar 2 .

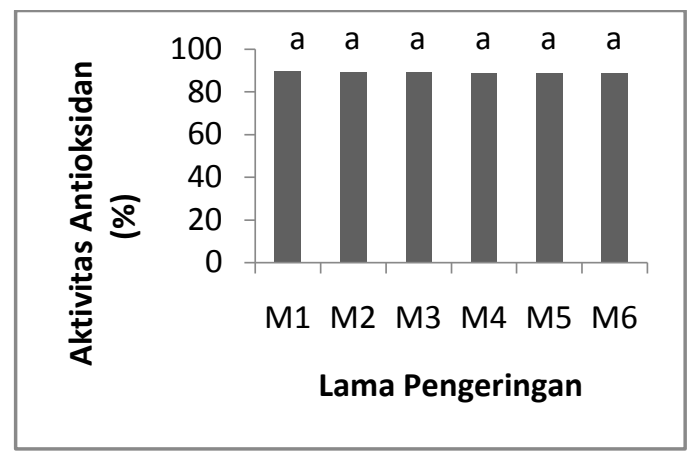

Gambar 2. Grafik Pengaruh Lama Pengeringan terhadap Aktivitas Antioksidan Teh Daun Kersen

Gambar 2 menunjukkan bahwa perlakuan lama pengeringan memberikan pengaruh yang tidak berbeda nyata terhadap aktivitas antioksidan daun kersen kering. Semakin lama proses pengeringan maka aktivitas antioksidan pada daun kersen kering akan semakin menurun. Aktivitas antioksidan tertinggi dengan lama pengeringan 120 menit yaitu $89,68 \%$ dan terendah pada lama pengeringan 170 menit yaitu $88,60 \%$.

Hal ini sejalan dengan penelitian Sari (2015) menyatakan bahwa semakin lama proses pengeringan dan semakin panas pengeringan 
maka aktivitas antioksidan akan semakin turun.Hal ini dikarenakan antioksidan kuat akan rusak oleh panas dan pemasakan (Apriadji, 2008). Sependapat dengan hasil penelitian Rahmawati et al. (2013) dalam Sari (2015) bahwa aktivitas antioksidan turun pada suhu tinggi.Semakin tinggi suhu dan lama pemanasan mengakibatkan senyawa metabolit sekunder yang bertindak sebagai antioksidan (senyawa flavonoid) rusak.Penelitian Hartanti dan Sri (2009) dalam Sari (2015) juga menunjukkan bahwa perbedaan perlakuan preparasi bahan baku berpengaruh terhadap aktivitas antioksidan. Pada bahan baku yang mengalami proses pengeringan, aktivitas antioksidan yang dihasilkan lebih kecil, hal ini disebabkan karena terjadinya degradasi atau kerusakan senyawa flavonoid selama proses pengeringan. Beberapa senyawa antioksidan mengalami kerusakan sehingga aktivitas antioksidannya turun.

\section{Kadar Abu}

Berdasarkan data hasil pengamatan dan analisis keragaman bahwa perlakuan lama pengeringan memberikan pengaruh yang tidak berbeda nyata terhadap kadar abu teh daun kersen dapat dilihat pada gambar 3 .

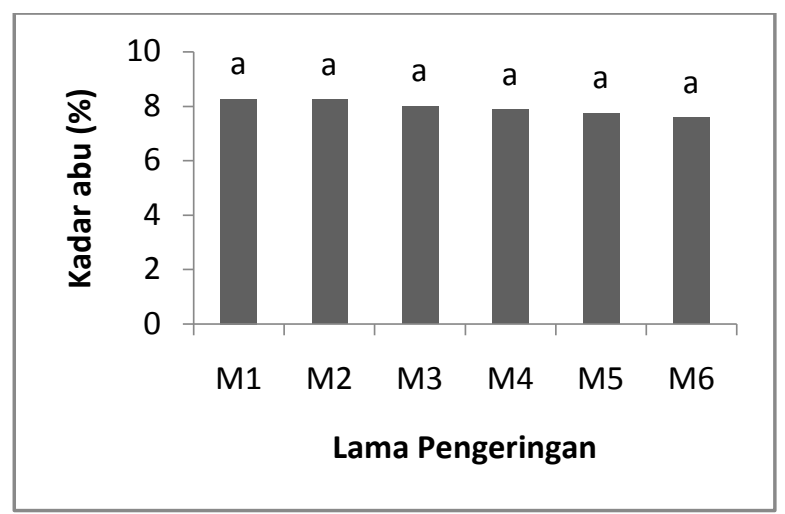

Gambar 3. Grafik Pengaruh Lama Pengeringan terhadap Kadar Abu Teh Daun Kersen.

Gambar 3 menunjukkan bahwa kadar lama pengeringan memberikan pengaruh yang tidak berbeda nyata terhadap kadar abu daun kersen kering. Semakin lama pengeringan maka kadar abu akan semakin berkurang. Perlakuan lama pengeringan 120,130,140, 150, 160, 170 dan 180 menit berturut-turut menghasilkan nilai kadar abu total tidak jauh berbeda. Apabila kadar air dari suatu bahan tinggi maka komposisi kimia dari suatu bahan tersebut akan menurun termasuk kadar abu. Substansi mineral bertanggung jawab atas perubahan koloid dan langsung berpengaruh pada metabolisme sel. Kandungan mineral dalam daun teh cukup banyak. Dimana mineral berfungsi sebagai pembentuk enzim didalam tubuh, termasuk antioksidan. Kandungan mineral yang terdapat dalam daun kersen yaitu kalsium dan mangan. Kalsium adalah mineral penting dalam proses pembentukan tulang. Mangan merupakan koenzim berbagai metallo enzim dan juga sebagai enzim akivator. Metallo enzim berperan penting dalam menghancurkan radikal bebas. Konsentrasi mangan yang relatif tinggi mampu menyumbang $10 \%$ dari kebutuhan tubuh.

\section{Mutu Fisik}

Tabel 2. Hasil pengamatan parameter fisik terdiri dari analisis kadar ekstrak dalam air. Adapun hasil analisis keragamanannya dapat dilihat dalam T

\begin{tabular}{l} 
Parameter Signifikansi \\
Kadar Ekstrak dalam NS \\
air \\
\hline Keterangan: \\
S = Signifikan (berbeda nyata) \\
NS = Non Signifikan (tidak berbeda nyata) \\
6. Kadar Ekstrak dalam Air
\end{tabular}

Berdasarkan data hasil pengamatan dan analisis keragaman bahwa perlakuan lama pengeringan memberikan pengaruh yang tidak berbeda nyata terhadap kadar ekstrak dalam air teh daun kersen dapat dilihat pada gambar 4. 


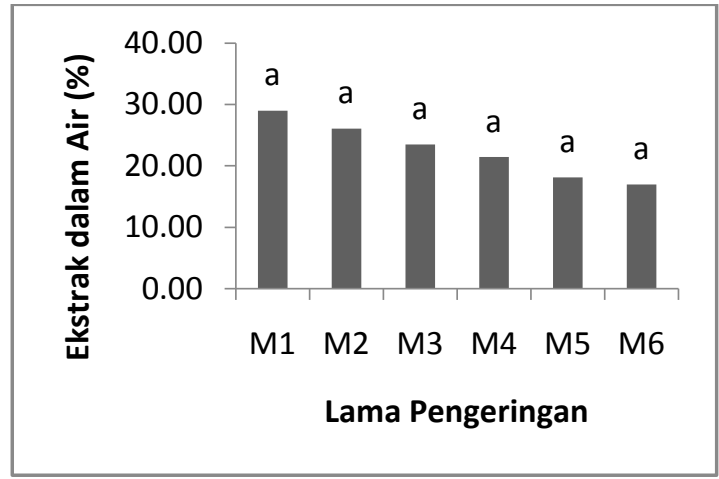

Gambar 4. Grafik Pengaruh Lama Pengeringan terhadap Kadar Ekstrak dalam Air Teh Daun Kersen.

Gambar 4 menunjukkan bahwa lama pengeringan memberikan pengaruh yang tidak berbeda nyata terhadap kadar ekstrak dalam air teh daun kersen. Semakin lama proses pengeringan maka kadar ekstrak dalam air teh daun kersen akan semakin berkurang. Hasil kadar ekstrak dalam air yang didapatkan dalam grafik dengan nilai tertinggi yaitu pada perlakuan lama pengeringan 120 menit menghasilkan nilai kadar ekstrak dalam air yaitu 28,99\% dan terendah pada perlakuan lama pengeringan 170 menit yaitu $16,99 \%$. Hal ini dikarenakan kadar ekstrak dalam air pada teh daun kersen berpengaruh terhadap lama pengeringan.

Prinsip yang bekerja pada proses ekstraksi adalah difusi, yaitu perbedaan konsentrasi antara larutan didalam sel dan konsentrasi cairan ekstraksi diluar sel. Bahan pelarut mengalir dari luar (konsentrasi tinggi) ke dalam sel (konsentrasi rendah) yang menyebabkan protoplasma membengkak sehingga kandungan senyawa metabolit sekunder yang berada di dalam sel akan mengalir atau berdifusi keluar sel (Achmadi 1992 dalam Agustiningrum 2004). Prinsip ini secara tidak langsung dapat mengakibatkan perbedaan banyaknya filtrat yang dihasilkan dari perendaman dan penyaringan setiap sampel. Perbedaan ini karena perbedaan keterikatan antara pelarut dengan jaringan sel setiap sampel berbeda.

\section{Mutu Organoleptik}

Tabel 3. Hasil Analisis Keragaman Parameter organoleptik teh daun kersen

\begin{tabular}{|c|c|c|}
\hline \multirow[b]{2}{*}{ Parameter } & \multicolumn{2}{|c|}{ Signifikansi } \\
\hline & Hedonik & Skoring \\
\hline Rasa & $\mathrm{S}$ & $\mathrm{S}$ \\
\hline Aroma & S & $\mathrm{S}$ \\
\hline Warna & NS & S \\
\hline
\end{tabular}

Keterangan:

$\mathrm{S}=$ Signifikan (berbeda nyata)

NS = Non Signifikan (tidak berbeda nyata)

\section{Rasa (Hedonik dan skoring)}

Pengaruhlama pengeringan terhadap rasa (hedonik dan skoring) teh daun kersen dapat dilihat pada gambar 5 .

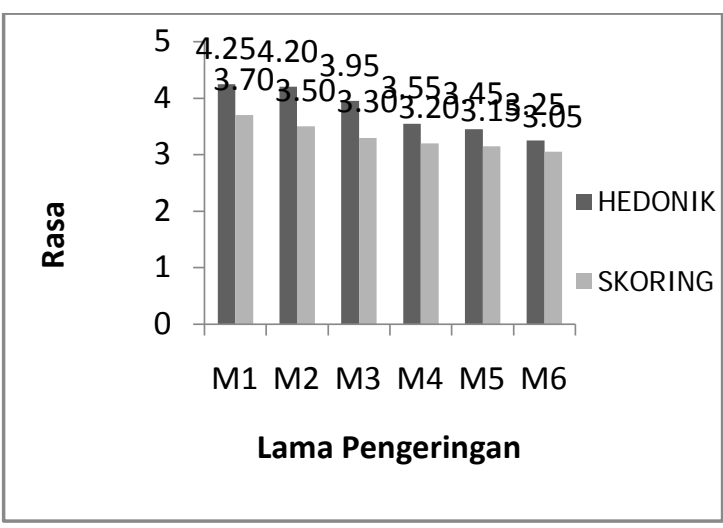

Gambar 5.Grafik Pengaruh Lama Pengeringan terhadap Rasa (Hedonik dan Scoring) Teh Daun Kersen.

Gambar 5 menunjukkan bahwa menunjukkan bahwa terjadi penurunan nilai kesukaan rasa hedonik dan skoring dari lama pengeringan 120-170 menit dengan nilai tertingi yaitu pada kontrol 4,95 dan terendah pada perlakuan lama pengeringan 170 menit yaitu 3,25 . Pada penilaian karakteristik rasa teh daun kersen, panelis memberikan nilai rasa teh daun kersen dari segi hedonik dengan keriteria amat sangat tidak suka sampai amat sangat suka. Rata-rata panelis memberikan penilaian agak tidak suka dan tidak suka. Sedangkan pada penilaian skoring nilai tertinggi juga terdapat 
pada perlakuan kontrol yaitu 4,35 dan terendah pada lama pengeringan 170 menit yaitu 3,05. Panelis memberikan nilai rasa dari segi skoring dengan keriteria rasa kersen amat sangat pahit sampai rasa teh amat sangat tidak pahit. Ratarata panelis pemberikan penilaian rasa kersen pahit dan rasa kersen agak pahit.

Semakin lama proses pengeringan maka tingkat kesukaan panelis akan semakin menurun. Hal ini dikarenakan semakin lama pengeringan maka teh daun kersen akan menghasilkan rasa sepat. Menurut Sriyadi (2012) bahwa pada daun teh terkandung senyawa polifenol yang larut dalam air panas dan menimbulkan rasa sepet dan pahit pada seduhan yang menentukan kualitas teh. Kandungan polifenol teh terdiri atas enam macam katekin dan turunannya yang besarnya bergantung pada klon dan cuaca pada saat panen. Enam macam katekin tersebut yaitu catechin (C), gallocatechin (GC), epicatechin (EC), epigalocatechin (EGC), epicatechin galate (ECg), dan epigalocatechin galate (EGCg).

\section{a. Aroma (Hedonik dan Skoring)}

Pengaruh lama pengeringan terhadap aroma (Hedonik dan skoring) teh daun kersen dapat dilihat pada gambar 6 .

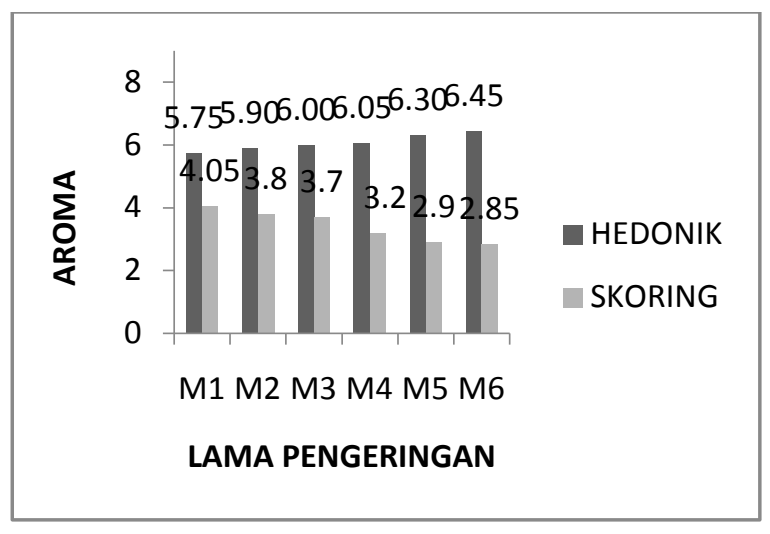

Gambar 6. Grafik Pengaruh Lama Pengeringan terhadap Aroma (Hedonik dan Scoring) Teh Daun Kersen.
Gambar 6 menunjukkan bahwa menunjukkan bahwa perlakuan lama pengeringan memberikan pengaruh yang tidak berbeda nyata pada uji hedonik dan memberikan pengaruh yang berbeda nyata pada uji skoring. Pada penilaian karakteristik aroma (hedonik) pada teh daun kersen, panelis memberikan penilaian terhadap aroma yaitu netral dan agak suka dengan kisaran nilai tertinggi pada perlakuan lama pengeringan 170 menit yaitu 6,45 dan nilai terendah pada perlakuan kontrol yaitu 5, 40. Sedangkan uji organoleptik aroma (skoring) nilai tertinggi pada kontrol yaitu 4,85 dan nilai terendah pada lama pengeringan 170 menit yaitu 2,85. Panelis memberikan penilaian aroma kersen sangat khas dan aroma kersen agak khas.

Hal ini dikarenakan semakin lama pengeringan maka penilaian panelis terhadap aroma (hedonik) teh daun kersen akan semakin suka, sedangkan untuk aroma (skoring) yaitu semakin lama pengeringan maka penilaian panelis terhadap aroma teh daun kersen yaitu aroma kersen sangat khas. Menurut ciptadi dan nasution (1979) menyatakan bahwa senyawa pembentuk aroma teh terutama terdiri dari minyak atsiri yang bersifat mudah menguap dan bersifat mudah direduksi sehingga dapat menghasilkan aroma harum pada teh.

\section{b. Warna (Hedonik dan Skoring)}

Pengaruh lama pengeringan terhadap rasa (Hedonik dan skoring) teh daun kersen dapat dilihat pada gambar 7 . 


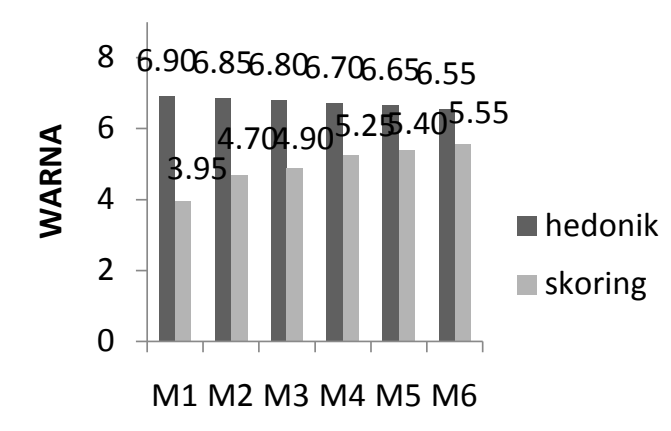

LAMA PENGERINGAN

Gambar 7. Grafik Pengaruh Lama Pengeringan terhadap Warna (Hedonik dan Scoring) Teh Daun Kersen.

Gambar 7 menunjukkan bahwa menunjukkan bahwa perlakuan lama pengeringan memberikan pengaruh yang berbeda nyata pada uji hedonik dan uji skoring warna. Pada penilaian karakteristik warna (hedonik) pada teh daun kersen, panelis memberikan penilaian terhadap warna yaitu agak suka dengan kisaran nilai tertinggi pada perlakuan kontrol yaitu 6,95 dan nilai terendah pada perlakuan lama pengeringan 170 menit yaitu 6,55. Sedangkan uji organoleptik warna (skoring) nilai tertinggi pada kontrol yaitu 6,20 dan nilai terendah pada lama pengeringan 120 menit yaitu 3,95. Panelis memberikan penilaian warna yaitu hijau kekuningan dan kuning kecoklatan.

Hal ini dikarenakan semakin lama proses pengeringan, panelis memberikan penilaian warna kesukaan semakin menurun. Sedangkan warna (skoring), semakin lama pengeringan warna yang dihasilkan akan semakin kecoklatan. Proses pengeringan membuat daun menjadi berwarna gelap, karena terjadi pemecahan klorofil dan terlepasnya unsur tannin.Wama pada daun disebabkan oleh kandungan zat wama yang terdapat di dalamnya. Kandungan zat wama tersebut disebut pigmen. Daun yang berwarna hijau disebabkan oleh adanya pigmen klorofil. Ada dua jenis klorofil yang telah diketahui, yaitu klorofil a dan klorofil b. Pigmen klorofil bersifat peka terhadap panas dan tidak stabil. Klorofil dalam tanaman terdapat dalam bentuk ikatankompleks dengan molekul protein dan lemak. Bila daun dipanaskan, maka protein akan terdenaturasi dan klorofil dilepaskan. Pemanasan juga dapat merusak ikatan antara senyawa nitrogen dan magnesium yang terdapat pada klorofil. Ketika magnesium dibebaskan maka tempatnya akan digantikan oleh dua molekul hydrogen sehingga terbentuk formasi baru yaitu feofitin yang berwarna hijau kecoklatan. Pada tingkat selanjutnya, pergantian gugus pada atom $\mathrm{C}$ dengan atom hydrogen menyebabkan feofitin berubah menjadi pyrofeofitin yang berwarna kecoklatan (Sofia, 2004)..

Menurut Fennema (1996)dalam (Sofia, 2004), setelah pemanasan 15 menit dengan suhu $121^{\circ} \mathrm{C}$ maka klorofil akan terdegradasi dengan cepat membentuk feofitin, tapi apabila pemanasan terus dilanjutkan, jumlah feofitin akan menurun dan membentuk pyrifeofitin. Jadi perubahan wama daun akibat pemanasan dikarenakan terbentuknya formasi baru dari klorofil menjadi feofitin dan pyrofeofitin. Pada pemanasan $50^{\circ} \mathrm{C}$, sebagian besar daun masih berwarna hijau. Hal ini dikarenakan ikatan Mg masih dapat dipertahankan. Pada pemanasan $65^{\circ} \mathrm{C}$ hanya sebagian klorofil yang sudah berubah menjadi feofitin yang berwarna hijau kecoklatan, sedangkan pada pemanasan $80^{\circ} \mathrm{C}$ sebagian besar klorofil sudah berubah menjadi pyrofeofitin yang berwarna kecoklatan.

\section{SIMPULAN DAN SARAN}

Berdasarkan hasil pengamatan, analisis keragaman dan pembahasan yang terbatas 
pada ruang lingkup penelitian, maka dapat ditarik kesimpulan bahwa pengaruh lama pengeringan memberikan pengaruh yang berbeda nyata terhadap beberapa parameter, di antaranya kadar air, parameter rasa, aroma (hedonik) dan rasa, aroma, warna (scoring) untuk organoleptik teh daun kersen.Pengaruh lama pengeringan memberikan pengaruh yang tidak berbeda nyata terhadap aktivitas antioksidan, kadar abu dan parameter warna (hedonik) untuk organoleptik teh daun kersen.Pengeringan selama 170 menit menghasilkan teh daun kersen dengan mutu terbaik untuk parameter kimia yaitu kadar air 3,05\%, aktivitas antioksidan 88,60\%, kadar abu $7,58 \%$ dan kadar ekstrak dalam air 7,58\%, sedangkan untuk parameter organoleptik pada pengeringan 120 menit dengan warna (Kuning kehijauan), aroma (kersen agak khas) yang disukai serta rasa (kersen pahit) yang tidak disukai oleh panelis.

\section{DAFTAR PUSTAKA}

[1] Adri, D. dan Hersoelistyorini, W., 2013. Aktivitas Antioksidan dan Sifat Organoleptik Teh Daun Sirsak (Annona muricata linn.) Berdasarkan Variasi Lama Pengeringan. Jurnal Pangan dan Gizi. 04 (7): 1 - 2.

[2] Badan Standarisasi Nasional., 1995. SNI 01-3757-1995. Standar Persyaratan Mutu Teh. Dewan Standarisasi Nasional. Jakarta.

[3] Ciptadi, W. Dan M.Z. Nasution. 1979. Mempelajari Cara Pemanfaatan Teh Hitam Mutu Rendah untuk Pembuatan Teh Dadak. IPB. Bogor.
[4] Hanafiah, K. A., 2014. Rancangan Percobaan: Teori dan Aplikasi. Edisi Ketiga. PT. Raja Grafindo Persadaj akarta.J akarta.

[5] Matondang, S., 1989. Pengeringan BijiBijian Hasil Pertanian. Fakultas Pertanian Universitas Sumatra Utara. Medan.

[6] Ismadi, Janu. 2011. Meneguk Manfaat dari Secangkir Teh. banten: Talenta Pustaka Indonesia.

[7] Sari, Galuh Prapita., 2011.Studi Budidaya Dan Pengaruh Lama Pengeringan Terhadap Jahe Merah (Zinggiber Officinale Rosc.). Program Studi Agroteknologi Fakultas Pertanian dan Peternakan Universitas Islam Negeri Sultan Syarif Kasim. Riau Pekanbaru.

[8] Sari, I., Titania, M., dan Sadli, 2016. The Cytotoxic Activity Of N-Hexane Extract Of Kersen(Muntingia calabura linn.) Leaves Using The Brine Shrimp Lethality Test (Bsit) Method. Jurnal Natural. Vol. 16 (2). Hal: 1141-8513.

[9] Sari, Mei Ambar., 2015. Aktivitas Antioksidan Teh Daun Alpukat (Persea Americana Mill) Dengan Variasi Teknik Dan Lama Pengeringan. Naskah Publikasi. Program Studi Pendidikan Biologi Fakultas Keguruan Dan IImu Pendidikan Universitas Muhammadiyah Surakarta.

[10] Sofia, D., 2004. Antioksidan dan Radikal. www.chem-is.try.com (Diakses tanggal03 Maret 2017).

[11] Sriyadi, Bambang., 2012. Seleksi klon teh assamica unggul berpotensi hasil dan kadar katekin tinggi. Jurnal Penelitian Teh dan Kina 15(1) 2012: 110.

[12] Winarno, F.G. 1993. Kimia Pangan dan Gizi. PT. Gramedia Pustaka Utama. Jakarta. 